\title{
OBSERVATIONS ON THE EFFECT OF VAGUS AND SYMPA- THETIC STIMULATION ON THE CORONARY FLOW OF THE REVIVED HUMAN HEART
}

\author{
By W. B. KOUNTZ, E. F. PEARSON AND K. F. KOENIG \\ (From the Department of Medicine, Washington University, and \\ the Barnes Hospital, St. Louis)
}

(Received for publication June 20, 1934)

Our present knowledge of the nervous regulation of the human heart is dependent upon two sources of information. One is the direct observation of the effect of stimulation of the nerves in experimental animals with the assumption that the nerves act similarly in man; the second is from clinical observation.

A method has been devised by which the direct effect of stimulation of the vagus and sympathetic nerves can be studied in the human heart. Observations were made on eight subjects, three of whom met death suddenly. In these the bodies were obtained 10 minutes postmortem. Five others died of a chronic illness, one of aplastic anemia, one of pulmonary tuberculosis, and the other three of malignancy. Their bodies were obtained within $20^{\circ}$ minutes after death. The effect of drugs on the beating human heart was studied on a considerable group of other cases, some of which have been previously reported (1).

\section{METHOD}

Immediately after death the vagus and sympathetic nerves were isolated on both sides of the neck. The hearts were revived by perfusion through an aortic cannula from a reservoir (Number 1, Fig. 1) containing either whole blood or Locke's solution with 50 per cent blood. The solutions were maintained at $37^{\circ} \mathrm{C}$. by passing them through a series of coils in a water bath. The reservoir was adjusted to provide a pressure of $120 \mathrm{~mm}$. Hg. As soon as the heart began to beat strongly, large cannulae were inserted into the right coronary and into the circumflex branch of the left coronary artery. The cannulae served the twofold purpose of perfusing the coronary arteries directly and of measuring the coronary flow.

Previously three other reservoirs (designated as Numbers 2, 3 and 4, Fig. I) had been set up. Pressure could be regulated by adjusting the height of the reservoirs above the heart. Reservoir 2 contained oxygenated Locke's solution. Reservoir 3 contained sodium chloride solution which 


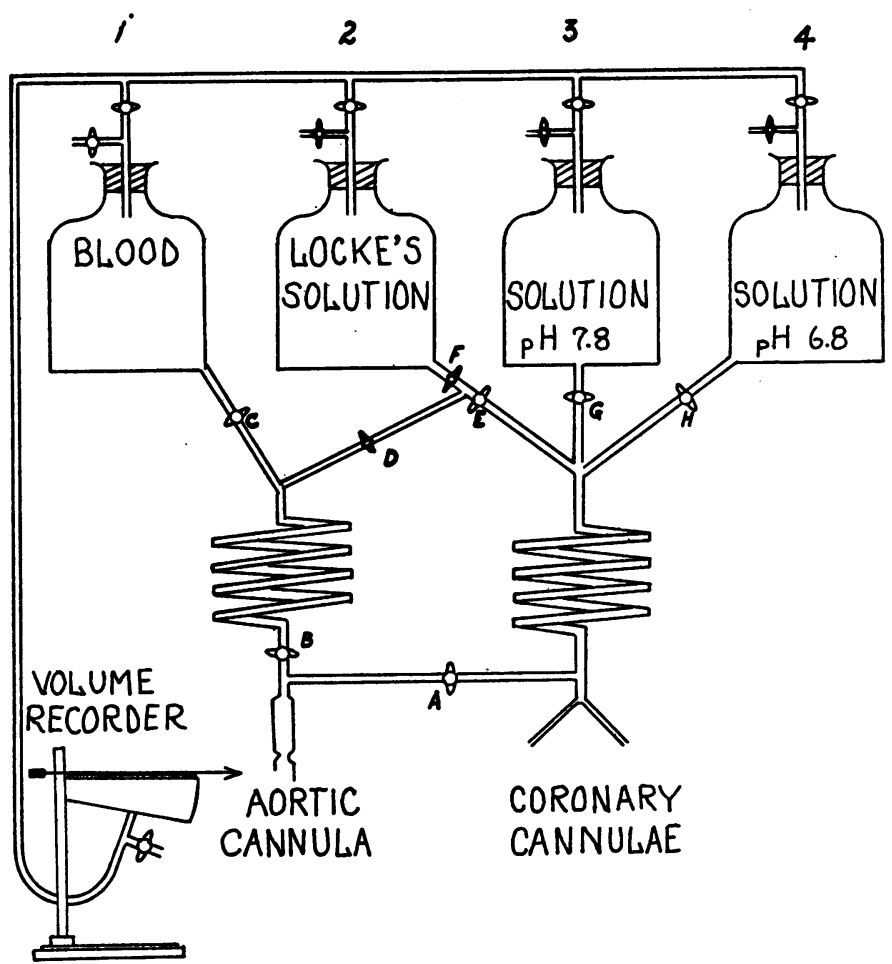

Fig. I. A Schematic Drawing of the Perfusion System

When it was desired to pass blood into the aorta, stopcocks $C$ and $B$ were opened. By opening stopcock $A$ blood would pass into the coronary cannulae, when $C$ and $B$ were open. To perfuse the aortic cannulae with Locke's solution stopcock $C$ was closed and $F, D$ and $B$ were opened. Opening of $E$ permitted the fluid to pass into the coronary cannulae.

When the heart was arrested with fluid from reservoir 3, stopcocks $G$ and $A$ were opened. After the heart had been stopped, stopcock $A$ was closed, while $F, D$ and $B$ were opened. Thus Locke's solution was perfused into the aorta, while the solution $\mathrm{pH} 7.8$ was perfused into the coronary arteries.

When the heart was arrested with fluid from reservoir 4, stopcocks $H$ and $A$ were opened. After the heart was arrested and the flow into the coronary arteries was being measured, stopcock $A$ was closed and $F, D$ and $B$ were opened.

The level of the fluid in the two reservoirs was kept at the same height above the heart by a screw adjustment attached to the stand, which was carefully adjusted by one observer as the fluid ran out.

at the beginning of the experiment had a $\mathrm{pH}$ of 8.0 and at the end a $\mathrm{pH}$ of 7.4. Reservoir 4 contained sodium chloride solution of $\mathrm{pH} 6.6$ at the beginning of the experiment and a $\mathrm{pH} 6.9$ at the end. All reservoirs were connected by rubber tubing to the cannulae in the coronary arteries and in the aorta. The outflow from each reservoir could be measured by a volumetric recorder. 
Standard rate of coronary flow'. The standard rate of flow into the coronary arteries was obtained by lowering the pressure of reservoir 1 and 2 to $80 \mathrm{~cm}$. above the heart $(60 \mathrm{~mm}$. $\mathrm{Hg})$. The object of lowering the pressure was twofold. From earlier experiments it was found that perfusion with saline solutions at a high pressure for any considerable period produced edema of the heart muscle, not prevented by addition of acacia to the solution. At a relatively low pressure, however. Locke's solution did not produce edema. The second reason was that the beat of the heart was weak and it has been pointed out by Häusler (2) that uncler such circumstances, unless the perfusion pressure is low (3), the systolic phase of the heart does not exert its usual effect of inhibiting the coronary flow.

The coronary cannulae were disconnected from reservoir 1 by closing stopcock $A$ and opening stopcock $E$. Oxygenated Locke's solution was then passed through the coronary arteries and blood through the aortic cannulae. The rate of flow into the coronary arteries was recorded. In addition, the heart rate and time were registered on a moving drum. After a standard record had been obtained, the vagus and svmpathetic nerves were stimulated and the coronary flow and heart rate were again recorded.

Stimulation of nerie's in beating heart. It was found that stimulation of the sympathetic nerve as far up as the lower border of the middle cervical ganglion usually gave an accelerator response, therein differing from that of other mammals. The point chosen for stimulation was just below the inferior cervical ganglion. I ligature had been passed around the sympathetic trunk in such a way as to include all branches from the inferior pole of the ganglion and all branches which apparently came from the nerve at this level. The vagus was stimulated at a point just lateral to the middle cervical ganglion, care again being taken to look for and include within the ligature the superior cardiac branch of the vagus nerve when it was present. In three cases it could not be found and presumably was incorporated in the vagus sheath. The nerve was stimulated just peripheral to the ligature which was approximately in the same region in all experiments.

The degree of stimulation was always the same and was determined roughly by the minimum amount of current necessary to produce maximal slowing of the heart when the vagus was stimulated. The secondary coil was usually set at $4 \mathrm{~cm}$. When the vagus had no influence on the ventricular rate the coil was arbitrarily set at $4 \mathrm{~cm}$.

Stimulation of neres in the arrested heart. After the stanclard rate of flow had been recorded the pressure was raised to $162 \mathrm{~cm}$. above the bodly and the heart was perfused from reservoir 1 for a short period. Hearts were then arrested by alkaline or acid solutions according to the method of Iwai (11).

Four hearts were arrested first by perfusion both through the aortic 
and coronary cannulae from reservoir 3 which contained a solution at a $\mathrm{pH}$ of 8.0, chosen to cause arrest in a state of increased tone (11). The system of reservoirs was adjusted to $80 \mathrm{~cm}$. above the heart $(60 \mathrm{~mm}$. of $\mathrm{Hg}$ pressure) and fluid from the third reservoir was permitted to flow into the aorta and coronary cannulae by opening stopcock $G$ and $A$ and closing stopcock $C$ and $E$. No record of the flow was taken during the arrest of the heart. After the heart had stopped the remaining fluid in the reservoir was removed and Locke's solution at a $\mathrm{pH}$ of 7.4 was added. This was done because in previous experiments it had been found that no nervous effect could be demonstrated in hearts perfused with a $\mathrm{pH}$ so acid or alkaline as to be barely compatible with life. Care was taken in the transfer of fluid to prevent air from entering the perfusion tubes. A record was made of the flow into the coronary arteries of the arrested heart from reservoir 3 . The aortic cannula was perfused from reservoir 2 and the flow from this flask was not measured. The vagus and sympathetic nerves were stimulated and a record made.

The heart was then revived by first washing out the vessels with oxygenated Locke's solution followed by blood from reservoir 1 at a pressure of $120 \mathrm{~mm}$. $\mathrm{Hg}$.

In a second series of four individuals the hearts were arrested by perfusion from reservoir 4 containing sodium chloride at $\mathrm{pH} 6.6$, a solution chosen to arrest the heart in a state of decreased tone. The effect of vagus and sympathetic stimulation was observed and the heart was revived as before.

Usc of drugs. In order to determine the dependence of the coronary flow on local cardiac vascular factors, the action of five drugs was studied both in beating and in arrested hearts. In these experiments it was desired to compare drugs which have a predominating vascular effect with others which are known to exert their major effect upon the heart muscle.

Histamine, 0.2 cc. $1: 10,000$, was selected as a strong vasodilator (4), and pituitrin, $0.2 \mathrm{cc}$., for its powerful vasoconstrictor action (5). Epinephrine, $0.5 \mathrm{cc}$. $1: 10,000$, is known to strengthen the heart beat and to exert its primary effect on the heart muscle, its action on coronary vessels being variable (6) (7). The other substances were $\mathrm{CO}_{2}$ and large doses of sodium nitrite ( $5 \mathrm{cc}$. saturated solution), both of which are thought to dilate the coronary arteries but also to produce dilatation of the beating heart (8).

After the effect of the stimulation of the nerves had been determined in the arrested heart, the drugs were injected into the fluid perfusing the coronary arteries and their effect upon the coronary flow of the heart was noted. The drugs were added after stimulation of the nerves in order to avoid any permanent changes in the capillaries or heart muscle which might influence the effect of the nerves on the coronary flow. The order of injection was: (1) histamine, (2) pituitrin, (3) $\mathrm{NaNO}_{2}$ and (4) epi- 
nephrine. Ten minute intervals elapsed between each injection. Ali of the hearts were revived at the end of the experiment. The action of drugs on the perfused beating human hearts had been previously recorded in 40 hearts other than those in which the nerves had been stimulated (1).

Application of alkaline and acid solutions to coronary wessels. In order to study the effect of acid and alkaline solutions on the coronary vessels. small rings of the coronary arteries were cut and suspended by the method described by Cruickshank and Subba Rau (9). The temperature was raised to $37^{\circ} \mathrm{C}$. and acid solution $(\mathrm{pH} 6.5)$ and alkaline solution ( $\mathrm{pH} 7.5$ ) were substituted for the Locke's solution in which the rings were suspended. Epinephrine, pituitrin, sodium nitrite and histamine were added to each of the preparations after washing.

\section{RESULTS}

Effect of nerie stimulation on the coronary flow of the beating heart. In the strongly beating human heart stimulation of the peripheral end of the vagus nerve slowed the heart rate and increased the flow into the coronary arteries. Stimulation of the sympathetic nerve increased the heart rate and slowed the flow into the coronary arteries.

In four of the hearts there was complete dissociation of the ventricles and auricles. Under these circumstances stimulation of the nerves did not change the ventricular rate but had an exactly opposite effect on coronary flow, vagus stimulation decreasing it while stimulation of the sympathetic increased the flow.

Effect of drugs on the coronary flow of beating hearts. Pituitrin was found to slow the heart rate and decrease the coronary flow, showing its vasoconstrictor properties. Histamine increased the flow but did not change to any considerable degree the rate and amplitude of the heart beat. demonstrating its vasodilator effect. Sodium nitrite in large doses dilated the heart and increased the coronary flow. $\mathrm{CO}_{2}$, administered in appreciable amounts weakened the heart beat but increased the flow. The action of epinephrine was variable. Its first effect was an increase in flow which then fell below the standard rate after about 20 seconds (Table I.)

Effect of nere stimulation on coronary flow in arrested hearts. In hearts stopped by perfusion with a fluid of altered $\mathrm{pH}$ the rate of coronary flow was reduced when compared to the beating hearts.

In hearts arrested in a state of increased tone by perfusion with saline solution at a $\mathrm{pH}$ of 8.0 to 7.4 , vagus stimulation increased the flow into the coronary arteries. Sympathetic stimulation in two cases decreased the coronary flow, while in the other two it had no effect.

When the hearts were arrested in a state of decreased tone by perfusion with saline solution at a $\mathrm{pH}$ of 6.6 to 6.9 vagus stimulation had no influence on the coronary flow. Sympathetic stimulation on the other 


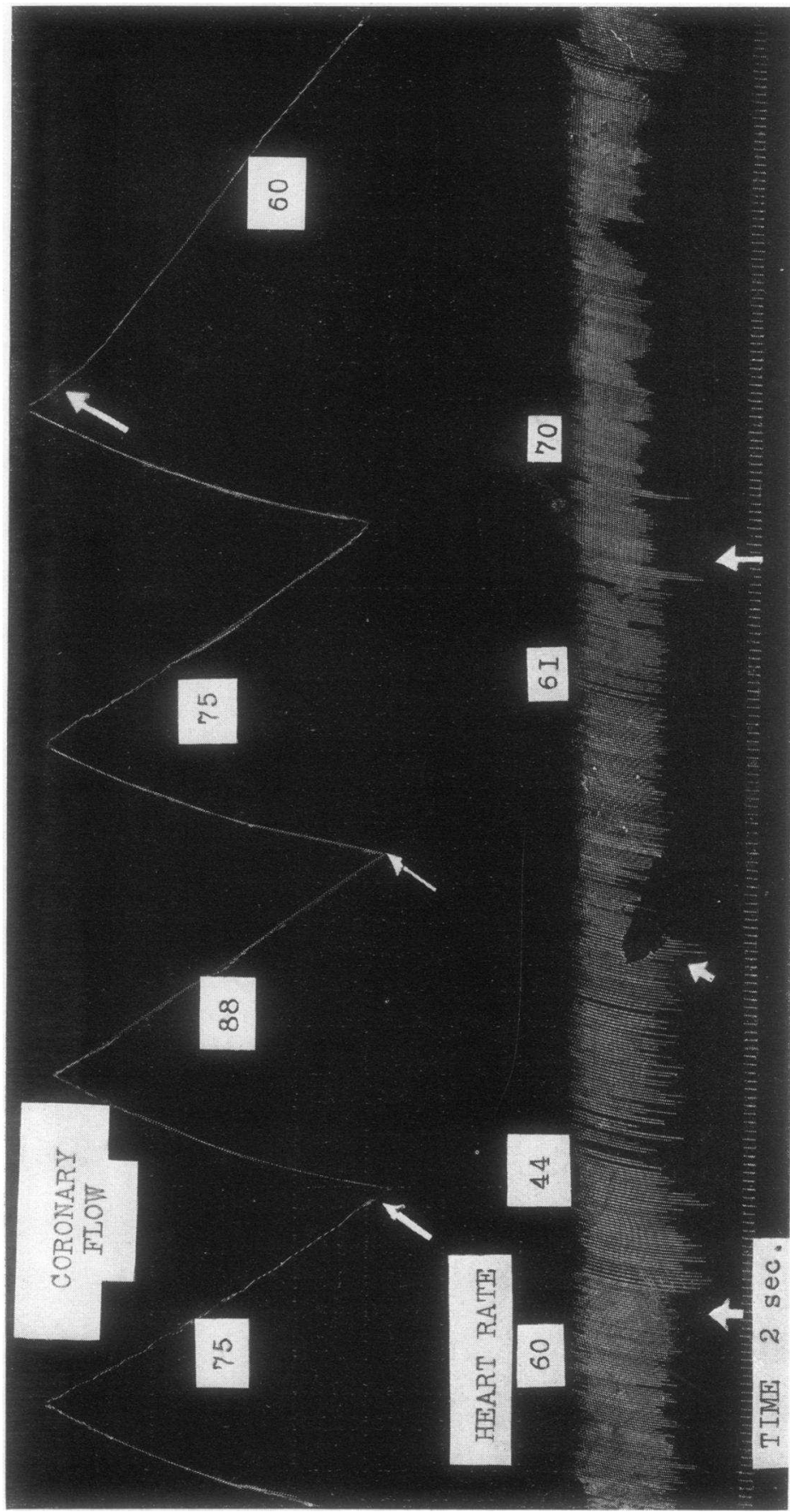

言芯

플

至要

is 0

플

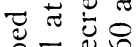

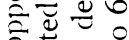

就焉包。

క

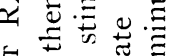

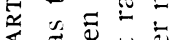

出粱志志

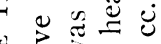

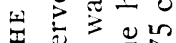

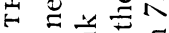

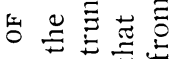

क्षे० एँ च

运吾

r.

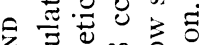

《 $\stackrel{\Xi}{\Xi} \infty$

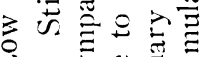

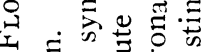

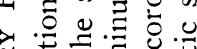

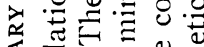

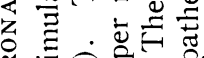

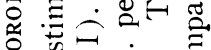

कo ठुं

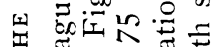

浽

4

(x) bo $=$ के

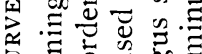

క $\Xi 00$

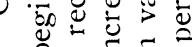

$\exists \stackrel{\Xi}{\Xi} \Xi \frac{n}{5}$

ن

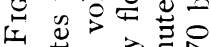
로요 导志志。 范 ㅎํㄴ 舍 년 西焉 范导导导 江 它艺它苛 


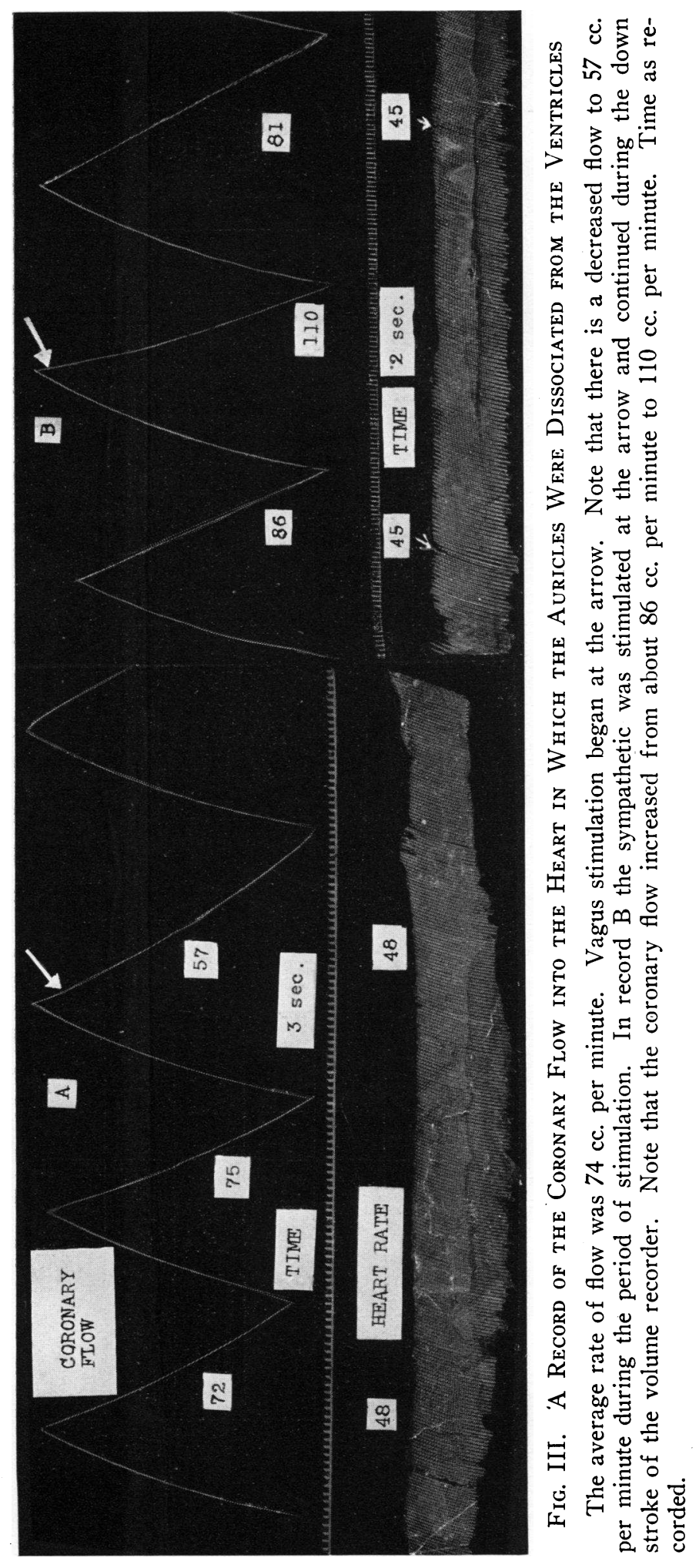


TABLE I

Effect of drugs on the beating human heart

\begin{tabular}{|c|c|c|c|c|c|}
\hline \multirow{2}{*}{ Drug } & \multirow{2}{*}{$\begin{array}{c}\text { Heart } \\
\text { num- } \\
\text { ber }\end{array}$} & \multicolumn{2}{|c|}{ Before drug } & \multicolumn{2}{|c|}{ After drug } \\
\hline & & $\begin{array}{l}\text { Heart } \\
\text { rate }\end{array}$ & $\begin{array}{l}\text { Coronary } \\
\text { flow* }\end{array}$ & $\begin{array}{l}\text { Heart } \\
\text { rate }\end{array}$ & $\begin{array}{l}\text { Coronary } \\
\text { flow* }\end{array}$ \\
\hline & & $\begin{array}{l}\text { per } \\
\text { minute }\end{array}$ & $\begin{array}{l}c c . \text { per } \\
\text { minute }\end{array}$ & $\begin{array}{c}\text { per } \\
\text { minute }\end{array}$ & $\begin{array}{l}\text { cc. per } \\
\text { minute }\end{array}$ \\
\hline \multirow[t]{2}{*}{ Adrenaline 1 cc. $1: 10,000 \ldots \ldots \ldots$} & 1 & 120 & 155 & 144 & 121 \\
\hline & 2 & 86 & 178 & 132 & 138 \\
\hline \multirow[t]{2}{*}{ Pituitrin 1 cc. Park Davis. } & 1 & 118 & 150 & 94 & 90 \\
\hline & 2 & 78 & 156 & 62 & 120 \\
\hline \multirow[t]{2}{*}{ Histamine 2 cc. $1: 10,000$. } & 1 & 123 & 148 & 123 & 168 \\
\hline & 2 & 72 & 160 & 81 & 168 \\
\hline \multirow[t]{2}{*}{ Sodium nitrite $1 \mathrm{cc}$. saturated solution. } & 1 & 122 & 153 & 127 & 198 \\
\hline & 2 & 84 & 164 & 89 & 212 \\
\hline
\end{tabular}

* Total coronary flow.

hand increased it. In Table II the effect of the stimulation is recorded. The hearts were all viable after completion of the experiments.

Effect of drugs on coronary flow of arrested hearts. In hearts arrested with increased tone $(\mathrm{pH} 8.0$ to 7.4$)$ pituitrin slowed the coronary flow. Histamine, on the other hand, varied in its effect, sometimes increasing and sometimes decreasing the flow. Sodium nitrite in large doses

TABLE II

Coronary flow and heart rate in the beating heart and the coronary flow in the arrested heart

\begin{tabular}{|c|c|c|c|c|c|c|c|c|c|c|c|c|}
\hline $\begin{array}{c}\text { Heart } \\
\text { num- } \\
\text { ber }\end{array}$ & $\begin{array}{l}\text { Stand- } \\
\text { ard } \\
\text { flow }\end{array}$ & $\begin{array}{l}\text { Heart } \\
\text { rate } \\
\text { beats }\end{array}$ & $\begin{array}{l}\text { Flow } \\
\text { vagus } \\
\text { stimu- } \\
\text { lation }\end{array}$ & $\begin{array}{c}\text { Rate } \\
\text { vagus } \\
\text { stimu- } \\
\text { lation }\end{array}$ & $\begin{array}{l}\text { Flow } \\
\text { sympa- } \\
\text { thetic } \\
\text { stimu- } \\
\text { lation }\end{array}$ & $\begin{array}{l}\text { Rate } \\
\text { sympa- } \\
\text { thetic } \\
\text { stimu- } \\
\text { lation }\end{array}$ & $\begin{array}{c}\text { Standard } \\
\text { coronary } \\
\text { flow } \\
\text { heart } \\
\text { arrested } \\
\text { by } \\
\text { acid }\end{array}$ & $\begin{array}{l}\text { Flow } \\
\text { vagus } \\
\text { stimu- } \\
\text { lation }\end{array}$ & $\begin{array}{l}\text { Flow } \\
\text { sympa- } \\
\text { thetic } \\
\text { stimu- } \\
\text { lation }\end{array}$ & $\begin{array}{c}\text { Standard } \\
\text { coronary } \\
\text { flow } \\
\text { hyart } \\
\text { arbsted } \\
\text { by } \\
\text { alkali }\end{array}$ & $\begin{array}{l}\text { Flow } \\
\text { vagus } \\
\text { stimu- } \\
\text { lation }\end{array}$ & $\begin{array}{l}\text { Flow } \\
\text { vagus } \\
\text { stimu- } \\
\text { lation }\end{array}$ \\
\hline & $\begin{array}{l}c c . \text { per } \\
\text { minute }\end{array}$ & $\begin{array}{c}\text { per } \\
\text { minute }\end{array}$ & $\begin{array}{l}c c \text { per } \\
\text { minute }\end{array}$ & $\begin{array}{c}\text { per } \\
\text { minute }\end{array}$ & $\begin{array}{l}c c \text { per } \\
\text { minute }\end{array}$ & $\begin{array}{c}\text { per } \\
\text { minute }\end{array}$ & $\begin{array}{l}c c \text { per } \\
\text { minute }\end{array}$ & $\begin{array}{l}c c . p e r \\
\text { minute }\end{array}$ & $\begin{array}{l}c c . \text { per } \\
\text { minute }\end{array}$ & $\begin{array}{l}c c \text { per } \\
\text { minute }\end{array}$ & $\begin{array}{l}c c . p e r \\
\text { minute }\end{array}$ & $\begin{array}{l}c c \text {. per } \\
\text { minute }\end{array}$ \\
\hline $1 *$ & 75 & 60 & 88 & 44 & 63 & 70 & & & & 35 & 59 & 35 \\
\hline 2 & 160 & 92 & 173 & 78 & 152 & 102 & 117 & 115 & 135 & & & \\
\hline 3 & 186 & 94 & 195 & 64 & 169 & 112 & 150 & 148 & 166 & & & \\
\hline 4 & 194 & 72 & 210 & 59 & 184 & 89 & & & & 150 & 175 & 108 \\
\hline $5 \dagger^{*}$ & 65 & 60 & 60 & 64 & 88 & 60 & 55 & 45 & 65 & & & \\
\hline $6 \dagger$ & 173 & 65 & 155 & 63 & 191 & 65 & & & & 117 & 142 & 96 \\
\hline $7 \dagger$ & 160 & 72 & 155 & 70 & 180 & 70 & & & & 154 & 176 & 125 \\
\hline $8 t^{*}$ & 70 & 48 & 57 & 48 & 78 & 52 & 72 & 66 & 93 & & & \\
\hline
\end{tabular}

* The flow through right coronary artery alone was measured.

+ Ventricles beat independently of the auricles. 


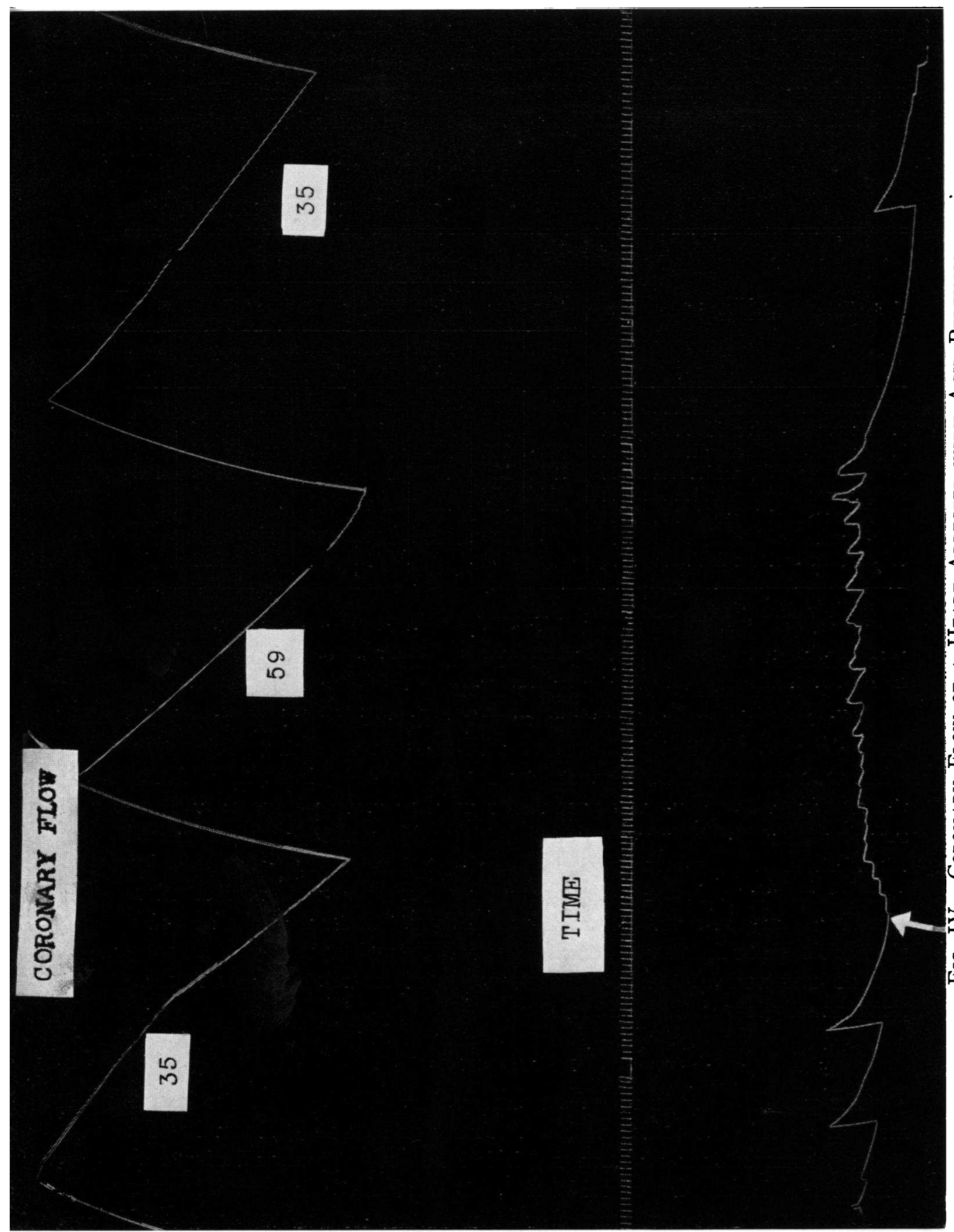

ఏ\zh24

古

龸完

范

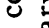

起

帘

ธี.

z

品

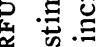

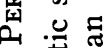

욜

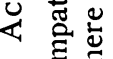

도오

岕芫

이몽

动

\%

《

봉

凷

ग

४ 芳

동 ․ㅡ 흥

3

ว

出

x

충

응 온

造 击

क

bo

要

ن 范

告 ญ芒 冚 3 동.

\% 월 엉

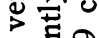

동

톤

造里 
in such a heart increased the flow into the coronary arteries. $\mathrm{CO}_{2}$, in one experiment, likewise increased the flow. Epinephrine definitely slowed it.

In hearts stopped by perfusing with an acid solution ( $\mathrm{pH} 6.6$ to 6.9) pituitrin usually slowed the flow into the coronary arteries. Histamine had little effect; sometimes a slight increase was noted when the drug was

TABLE III

Effect of drugs on the coronary flow of arrested human hearts

\begin{tabular}{|c|c|c|c|c|c|c|c|c|}
\hline \multirow{3}{*}{$\begin{array}{c}\text { Heart } \\
\text { number }\end{array}$} & \multicolumn{8}{|c|}{ Coronary flow, $c c$ per minule } \\
\hline & \multicolumn{2}{|c|}{ Adrenaline } & \multicolumn{2}{|c|}{ Pituitrin } & \multicolumn{2}{|c|}{ Histamine } & \multicolumn{2}{|c|}{ Sodium nitrite } \\
\hline & $\begin{array}{l}\text { Before } \\
\text { drug }\end{array}$ & $\begin{array}{l}\text { After } \\
\text { drug }\end{array}$ & $\begin{array}{c}\text { Before } \\
\text { drug }\end{array}$ & $\begin{array}{l}\text { After } \\
\text { drug }\end{array}$ & $\begin{array}{l}\text { Before } \\
\text { drug }\end{array}$ & $\begin{array}{l}\text { After } \\
\text { drug }\end{array}$ & $\begin{array}{c}\text { Before } \\
\text { drug }\end{array}$ & $\begin{array}{l}\text { After } \\
\text { drug }\end{array}$ \\
\hline $1 *$ Arrested with alkali. & 40 & 30 & 44 & 34 & 46 & 60 & 48 & 72 \\
\hline 2. Arrested with acid.. & 107 & 116 & 98 & 82 & 99 & 120 & 116 & 125 \\
\hline 3. Arrested with alkali. & 143 & 122 & 137 & 115 & 128 & 140 & 137 & 148 \\
\hline 4. Arrested with acid... & 137 & 152 & 143 & 125 & 140 & 158 & 133 & 142 \\
\hline 5.* Arrested with alkali. & 63 & 57 & 69 & 58 & 70 & 61 & 63 & 76 \\
\hline 6. Arrested with acid... & 136 & 108 & 123 & 116 & 127 & 150 & 138 & 144 \\
\hline 7. Arrested with alkali. & 144 & 127 & 144 & 148 & 134 & 153 & 146 & 168 \\
\hline 8.* Arrested with acid. . & 60 & 54 & 58 & 54 & 52 & 66 & 58 & 62 \\
\hline
\end{tabular}

* Flow through right coronary alone measured.

injected into the perfusate. Epinephrine increased the coronary flow while sodium nitrite and $\mathrm{CO}_{2}$ had no effect.

Effect of drugs on coronary vessels. Immersion of rings of the coronary artery at $37.5^{\circ} \mathrm{C}$. into an acid solution resulted in relaxation, while with alkaline solution constriction was observed. Pituitrin added to the alkaline solution usually produced a mild relaxation followed by constriction whereas in vessels relaxed by an acid solution, pituitrin caused constriction. Epinephrine produced a slight constriction in an alkaline solution and in a few experiments some relaxation in an acid solution. Usually no response was obtained by the drug. Sodium nitrite caused a slow prolonged relaxation in an alkaline solution, whereas in an acid solution no effect was noted. Histamine produced constriction in both solutions, usually less in the acid medium.

\section{DISCUSSION}

The question may be raised concerning the applicability of our instrument to the solution of this problem. Anrep and Segal (10) employed a string galvanometer so sensitive that it followed coronary flow during each heart beat. Hochrein's and Keller's (13) differential manometer may have been still more accurate. Our volume recorder was much less delicate and could not reveal rapid changes in coronary flow. Since, how- 
TABLE IV

Summary of effects of vagus and sympathetic stimulation and of certain drugs upon the coronary flow

Procedure

Stimulation of vagus nerve

Stimulation of sympathetic nerve

Stimulation of vagus nerve

Stimulation of sympathetic nerve

Stimulation of vagus nerve

Stimulation of sympathetic nerve

Stimulation of vagus nerve

Stimulation of sympathetic nerve

Injection of epinephrine

Injection of pituitrin

Injection of sodium nitrite

Injection of histamine
State of heart muscle

Normal rhythm

Normal rhythm

A. V. dissociation

A. V. dissociation

Heart arrested increased tone

Heart arrested increased tone

Heart arrested decreased tone

Heart arrested decreased tone

Normal rhythm

Heart arrested increased tone

Heart arrested decreased tone

Normal rhythm

Heart arrested increased tone

Heart arrested decreased tone

Normal rhythm

Heart arrested increased tone

Heart arrested decreased tone

Normal rhythm

Heart arrested increased tone

Heart arrested decreased tone
Changes in coronary

Increased

Decreased

Decreased

Increased

Increased

Decreased in two experiments

No change

Increased

Decreased

Decreased

Increased

Decreased

Decreased

Decreasded

Increase

Increased

No change

Increased

Variable

Increased

ever, we were chiefly interested in the change of state of cardiac muscle and since this itself takes place slowly, significant variations in coronary flow should have been apparent.

In a study of the dog's heart Anrep and Segal (10) found that stimulation of the vagus nerve decreased the coronary flow while sympathetic stimulation increased it. We were able to confirm these observations in human hearts when the auricles and ventricles were completely dissociated and the heart rate was not changed by stimulation of the nerves. Confirmation was lacking in hearts with normal mechanism where the rate of the ventricles was influenced by nerve stimulation.

Anrep has attributed his results to a direct effect of the cardiac nerves on coronary vessels, an explanation which may apply to our hearts with auriculoventricular dissociation. With normal cardiac mechanism, however, there was some additional factor which reversed the effect of stimulation of the nerves; and which appeared to be associated with change in the state of the heart muscle at varying rates. A study of Anrep's results, particularly with vagus stimulation, shows a similar phenomenon after a short initial effect in the opposite direction.

Anrep states that rate does not influence the coronary flow in a dog. This is apparently not true in the human heart unless weakening of the cardiac beat accompanies the changed rate. Thus we have found that a drug like atropine, which increases the rate but has little effect upon the strength of contraction, diminishes coronary flow, while pilocarpine, which 
decreases the heart rate without producing changes in the force of the contraction, increases the flow.

The results on arrested hearts can be explained only with difficulty on the basis of direct action of the nerves on coronary vessels. The acceptance of such an explanation would depend upon the assumption of a reversal of nerve effects under the two conditions. While this possibility has been demonstrated by Ten Cate (12), who showed that the action of nerves depends in part upon the ionic concentration of the perfusing solution, there is no evidence that such factors are active under the conditions of our experiments. The theory of changes in cardiac tone offers a more plausible explanation of the results. In the heart arrested by alkaline solutions (increased tone) the vagus nerve might diminish the tone to a more nearly normal state and therefore increase the coronary flow. In the dilated heart the vagus would lose its effect, but the sympathetic nerve, by increasing the tone to a more nearly normal state, might increase the flow. ${ }^{1}$

Still further analysis of the phenomenon is possible from the action of drugs on the arrested hearts and on the rings of the coronary artery. In the experiments on coronary rings the drugs which are known to act as primary vasoconstrictors or vasodilators, if they were active at all, always acted the same way, regardless of the solution in which the rings were suspended. On the other hand, those which are known to act by changing the state of the muscle acted differently in different solutions.

Likewise, in the perfused hearts epinephrine, which increases the force and rate of the heart beat, simulates the action of the sympathetic; while drugs (sodium nitrite and $\mathrm{CO}_{2}$ ), which decrease the force of the heart beat, simulate the action of the vagus. On the other hand the action of drugs which have a primary vasoconstrictor (pituitrin) and vasodilator (histamine) effect does not resemble that following stimulation of the nerves.

\section{SUM MARY}

1. The effect of vagus and sympathetic nerve stimulation on coronary flow was studied in the revived human hearts and in the same hearts arrested by alkaline and acid perfusate.

2. In the normal beating human heart vagus stimulation slowed the

1 The action of the cardiac nerves upon changing the phases of ventricular contraction aside from the change in heart rate associated with nerve stimulation has been noted by a number of observers. Chief among these observers have been Gaskell (14), Stefani (15) and Franck-Francois (16). Katz (17) and Wiggers and Katz (18) have investigated the subject in the mammalian heart by using systole-cycle ratio to eliminate the effect of rate and have come to the conclusion that the cardiac nerves, particularly the accelerators, do have a specific effect on the ventricular musculature. 
heart rate and increased the coronary flow. Sympathetic nerve stimulation increased the heart rate and slowed the coronary flow.

3. In hearts in which there was dissociation of auricular and ventricular contraction and in which the rate was not influenced by the nerves. vagus stimulation slowed the coronary flow, while sympathetic stimulation increased it.

4. In hearts arrested with increased tone, vagus stimulation increased the coronary flow while sympathetic stimulation in two cases decreased it. In hearts arrested in decreased tone by acid perfusate vagus stimulation had no effect, while sympathetic stimulation increased the flow.

5. The action of the nerves in these hearts was compared to that of drugs. It was found that drugs, which in the beating heart increased muscle action and decreased coronary flow, closely simulated the action of the sympathetic; while drugs, which dilated the beating heart and increased coronary flow, simulated vagus nerve stimulation. No such similarity was noted between nerve action and drugs which act primarily as vasoconstrictors or vasodilators of the coronary vessels themselves.

6 . The results of this group of experiments suggest that in man the cardiac nerves exert their most important action on coronary flow through changes in the state of the heart muscle.

The authors wish to express their appreciation of the cooperation of the staff of the Department of Pathology, and especially of Dr. Walter Siebert, for his assistance in some of the experiments.

\section{BIBLIOGRAPHY}

1. Kountz, William B., Studies on the coronary arteries of the human hearts. J. Pharmacol. and Exper. Therap., 1932, 45, 65.

2. Häusler, H., The coronary circulation. III. The dependence of changes in the coronary blood flow on cardiac and local vascular factors. J. Physiol., 1929, 68, 324.

3. Anrep, G. V., Davis, J. C., and Volhard, E., The effect of pulse pressure upon the coronary blood flow. J. Physiol., 1931, 73, 405.

4. Feldberg, W., and Schilf, E., Histamin. Seine Pharmakologie und Bedeutung für die Humoralphysiologie. Julius Springer, Berlin, 1930, $\mathrm{S} 127$.

5. Gruber, C. M., and Kountz, W. B., Some observations on the effect of pitressin upon the cardiovascular system. J. Pharmacol. and Exper. Therap., 1930, 39, 435.

6. Anrep, G. V., and Häusler, H. G., The coronary circulation. II. The effect of changes of temperature and of heart rate. J. Physiol., 1929, 67, 299.

7. Smith, F. M., Miller, G. H., and Graber, V. C., The action of adrenalin and acetyl-cholin on the coronary arteries of the rabbit. Am. J. Physiol., (Proc.) 1926, 76, 231.

8. Bodo, Richard, The effect of the "heart tonics" and other drugs upon the heart tone and coronary circulation. J. Physiol., 1928, 64, 364. 
9. Cruickshank, E. W. H., and Subba Rau, A., Reactions of isolated systemic and coronary arteries. J. Physiol., 1927, 64, 65.

10. Anrep, G. V., and Segal, H. N., The regulation of the coronary circulation. Heart, 1926, 13, 239.

11. Iwai, M., Untersuchungen über den einfluss der wasserstoffionenkonzentration auf die coronargefässe und die Heiztätigkeit. Arch. f. d. ges. Physiol., 1924, 202, 356.

12. Ten Cate, J., I'influence du calcium dans l'action du sympathique sur le coeur de grenouille. Arch. néerl. de physiol., 1926, 10, 498.

L' action du sympathique et du vagis sur le coeur de grenouille. Ibid., 1926, 10, 544.

13. Hochrein, M., and Keller, J., Untersuchungen am Koronarsystem. Arch. f. exper. Path. u. Pharmakol., 1931, 159, 300.

14. Gaskell, W. H., On the rhythm of the heart of the frog and on the nature of the action of the vagus nerve. Phil. Trans., 1882, 3, 993.

15. Stefani, A., Cardiovolume pression péricardique et activité de la diastole. Arch. ital. de biol., 1893, 18, 119.

16. Francois-Franck, Ch. A., Recherches expérimentales sur l'atonie cardiaque produite par le nerf pneumogastrique. Arch. de Physiol. normale et path., 1891, 3, 478.

17. Katz, L. N., Factors modifying the duration of ventricular systole. J. Lab. and Clin. Med., 1921, 6, 291.

18. Wiggers, C. J., and Katz, L. N., The specific influence of the accelerator nerves on the duration of ventricular systole. Am. J. Physiol., 1920, 53, 49. 